\title{
Evaluation of antimicrobial Activities of isolated compounds from the leaf of the white specie of Sesamum Indicum from Benue State, Nigeria
}

\section{${ }^{* 1}$ CHRISTIANA .E. OGWUCHE ${ }^{1}$, JOSEPH .O. AMUPITAN ${ }^{2}$, GEORGE .I. NDUKWE ${ }^{2}$}

\author{
${ }^{1}$ Department of Chemistry, Federal University of Petroleum Resource, Effurun, Nigeria \\ ${ }^{2}$ Department of Chemistry, Ahmadu Bello University Zaria, Kaduna State, Nigeria. \\ Tel: +2347037166612 ,
}

KEY WORDS: Anti-microbial, Benue, Pathogenic micro-organisms, Sesamum indicum leaves, Dry vacuum liquid chromatography (DVLC).

\begin{abstract}
The isolated compounds from the petroleum spirit, chloroform and methanol crude leaf extracts of the white specie of the leaf of the Sesamum indicum used by traditional medicinal practitioners for the management of infecticious diseases were investigated for in vitro antimicrobial activity against some organisms. The various extracts afforded compounds which had significant antimicrobial activities. The antimicrobial screening showed that all the pure isolates from the different solvent extracts were active against the organisms, Staphylococcus aureus, Streptococcus pyogenes, Salmonella typhi, Candida albicans, Candida krusei, and Candida tropicalis at various MIC's and (MBC/MFC)'s. The pure isolates from methanol and ethyl acetate fractions were all inactive against Bacillus cereus, Corynebacterium ulcerans, and Escherichia coli. Only the pure isolates from petroleum spirit and chloroform fractions showed activity against Bacillus cereus, Corynebacterium ulcerans, and Escherichia coli at an MIC of $0.5 \mathrm{mg} / \mathrm{ml}$ and MCB/MFC of $1 \mathrm{mg} / \mathrm{ml}$. Chromatographic techniques such as analytical TLC, Purification by dry vacuum liquid chromatography (DVLC) and Preparative TLC were used. @JASEM
\end{abstract}

http://dx.doi.org/10.4314/jasem.v18i4.2

\section{Introduction}

Throughout history, natural products from plants have played major sustaining roles in the lives of humans, especially as food sources and for medicinal purposes. Indigenous peoples living on their traditional territory histories largely rely on ethno medicinal plants for healthcare and they are therefore rich in ethno pharmacological knowledge, Uprety et al. (2010) and Birendra (2012). The use of natural products with therapeutic properties is as ancient as human civilization because medicinal since plants are capable of synthesizing an overwhelming variety of low molecular weight organic compounds called secondary metabolites, usually with unique and complex structures, Virendra et al (2012), Rajeev et al (2011), Sumit et al (2011), Singla (2012), Salim (2011) and Vidhu et al (2011). For thousands of years, plants have been known to be valuable sources of medicinal agents with proven potential of treating infectious diseases and with lesser side effects compared to synthetic drugs Cohen (1992), Gills (1992) and Nascimento (2000). Sesamum indicum of Pedaliaceae family, is an indigenous Benue plant of Nigeria and its leaves are reported to have antimicrobial activity as reported by Ijigah et al
(2011) Thus, there is still a tremendous amount of work to be done and these needs to be accomplished rapidly, before the natural habitat of the plants are destroyed Sofowora (1984).

MATERIALS AND PLANT MATERIAL The plant Sesamum indicum leaves were collected from Makurdi, Benue State, Nigeria. They were properly identified at the herbarium, Department of Biological Sciences, Ahmadu Bello University, Zaria. Thereafter, the leaves were dried for two weeks in the lab in readiness for the experiment.

Extraction: The classical procedure for obtaining organic constituents from dried plant tissue, was followed according to the procedure by Harborne (1984) and Sofowora (1982). This method involves the use of a Soxhlet apparatus and a range of solvents. Each extraction process was exhaustive and finally concentrated under reduced pressure. $546 \mathrm{~g}$ portion of the coarse powdered leaf material was packed into a soxhlet extractor thimble, which was operated at a temperature of $80^{\circ} \mathrm{C}$. The siphoning chamber of the extractor was plugged with glass wool. After packing the thimble with the leaf material 
into the chamber, another glass wool was placed above it before fixing the condenser. The soxhlet outlet was then fixed onto the round bottom flask (quick fit 500ml) containing anti-bumping chips and solvent mounted on a heating mantle and extracted exhaustively using petroleum spirit $\left(60-80^{\circ} \mathrm{C}\right)$, followed by chloroform, ethyl acetate and methanol. The extracts were evaporated using.

Chromatographic Separations: Thin-Layer chromatography (TLC) and column chromatographic $(D V L C)$ techniques were adopted for the isolation and purification processes. Pre-coated silica gel plates (Merck silica gel $60 \mathrm{~F}_{254}$ ) were used for the trial runs to determine the appropriate solvent combinations required to separate fairly well the components of the extracts.

Purification by dry vacuum liquid chromatography $(D V L C)$ : The extracts were purified using a dry vacuum column chromatographic technique. The eluting solvent system used was that in which the desired component had an $\mathrm{R}_{\mathrm{f}}$ value of 0.5 by TLC analysis. A sintered glass funnels (porosity 3), was loaded with silica gel under vacuum, ensuring that it was compacted and uniformly spread. The extracts were dissolved individually, in the various solvent which they dissolve wholly before preabsorption. All the procedure for preabsorption and proper packing was maintained. The column was eluted with various combinations of hexane, diethyl ether, ethyl acetate and methanol as fashioned out from analytical TLC. Starting with $100 \%$ of the least polar with an increasing polarity of $1 \%$ or $0.5 \%$ as the case may be, of the most polar of the desired solvents combination up to $100 \%$ of the most polar.

Antimicrobial Screening: Zone Of Inhibition: The antimicrobial activities of the various extracts from the plant Sesamum indicum were determined using some pathogenic microorganisms. The test microbes such as Staphylococcus aureus, Streptococcus pneumonia, Salmonella typhi, Candida albicans, Candida krusei, Klebsiella pneumonia, Escherichia coli, Microsporan rubrum, Pseudomonas aeruginosa and Candida tropicalis were obtained from the Department of Medical Microbiology A.B.U. Teaching hospital, Zaria. All the isolates were checked for purity and were maintained in slants of nutrient agar for the bacteria and slant of Sabouraud dextrose agar for the fungi. Well diffusion method was the method used to determine the antimicrobial activities of the extracts from the plant. o.1g of the extract was dissolved in $10 \mathrm{ml}$ of DMSO to obtain a concentration of the extracts. The active positive control used were sparfloxacin $2 \mathrm{mg} / \mathrm{ml}$ for the bacteria and flucozole $5 \mathrm{mg} / \mathrm{ml}$ for the fungi. This was the initial concentrations used to check the antimicrobial activities of the extracts from the plant. Mueller Hinton agar and Sabouraud dextrose agar were the media used as growth media and were prepared according to the manufacturer's instructions (Oxoids of England). Minimum inhibitory concentration of the extract was carried out on the microorganisms that were sensitive to the extract and was done using broth dilution method. Minimum Bactericidal and fungicidal concentration of the extracts were carried out to check whether the test microbes were killed or only their growth was inhibited.

Minimum inhibitory concentration: Minimum inhibitory concentration of the extract was carried out on the microorganisms that were sensitive to the extract and was done using broth dilution method. Nutrient broth was prepared according to the manufacturer's instructions as recommended by NCCLS (Farraro et al., 2000). 10ml was dispensed into test tubes and was sterilized at $121^{\circ} \mathrm{C}$ for 15 minutes, and the broth was allowed to cool. Minimum inhibition McFarland turbidity standard scale number 0.5 was prepared to give turbid solution. Normal saline was prepared and was dispensed into test tube and the test microorganism was then inoculated into the normal saline, incubation was at $37^{\circ} \mathrm{C}$ for $6 \mathrm{hrs}$, dilution of the microorganism in the normal was performed until the turbidity marched that of the McFarland by visual comparison at this point the microorganism had a concentration of about $1.5 \times 10^{8} \mathrm{cfu} / \mathrm{ml}$. Two-fold serial dilution of the extract in the broth was performed to obtain the concentrations of $10 \mathrm{mg} / \mathrm{ml}$, $5 \mathrm{mg} / \mathrm{ml}, 2.5 \mathrm{mg} / \mathrm{ml}, 1.25 \mathrm{mg} / \mathrm{ml}$ and $0.625 \mathrm{mg} / \mathrm{ml}$. The initial concentration was obtained by dissolving the extract $(0.1 \mathrm{~g})$ in the extracts in the broth $(10 \mathrm{mls})$, $0.1 \mathrm{ml}$ of the standard inoculated into the different concentrations of the extracts in the broth, was then inoculated at $37^{\circ} \mathrm{C}$ for $24 \mathrm{hrs}$ after which the test tubes were observed for turbidity (growth). The lowest concentrations of the extract which shows no turbidity was recorded as the minimum inhibitory concentrations.

Minimum bacteriocidal and fungicidal concentration: Minimum Bactericidal and fungicidal concentration of the extracts were carried out to check whether the test microbes were killed or only their growth was inhibited. Mueller Hunton and Sabouraud dextrose agars were prepared according to the manufacturer's instruction, boiled to dissolve and were sterilized at $121^{\circ} \mathrm{C}$ for 15 minutes, the media 
were cool to $45^{\circ} \mathrm{C}$ and the medium (20ml) was poured in to sterile Petri dishes, the plates were covered and allowed to cool and solidify. The contents of the MIC in the serial dilution was inoculated on to the media, the media were incubated at $37^{\circ} \mathrm{C}$ for $24 \mathrm{hrs}$ for the bacteria and at $30^{\circ} \mathrm{C}$ for $1-7$ days for fungi, after which the plate were observed for colonies growth. The MBC/MFC were the plate with lowest concentrations of the extract without colony growth.

\section{RESULTS AND DISCUSSION}

Discussion of results was carried out based on the various isolates from the crude solvent extracts.

Table 1: Antimicrobial screening of pure fractions isolated from the crude leaf extracts the plant Sesamum indicum extracts showing Zones of inhibition (mm)

\begin{tabular}{lllllll}
\hline Organisms & $\begin{array}{l}\text { Compound } \\
(1)\end{array}$ & $\begin{array}{l}\text { Compound } \\
(2)\end{array}$ & $\begin{array}{l}\text { Compound } \\
(3)\end{array}$ & $\begin{array}{l}\text { Compound } \\
(4)\end{array}$ & $\begin{array}{l}\text { Sparfloxacin } \\
(\mathrm{mm})\end{array}$ & $\begin{array}{l}\text { Fluconazole } \\
(\mathrm{mm})\end{array}$ \\
\hline S. aureus & 22 & 24 & 28 & 27 & 42 & 0 \\
S. pyogenes & 20 & 22 & 24 & 26 & 40 & 0 \\
E. coli & 0 & 0 & 25 & 22 & 32 & 0 \\
C. ulcerans & $\mathrm{NT}$ & $\mathrm{NT}$ & 22 & 0 & 29 & 0 \\
P. aeruginosa & $\mathrm{NT}$ & $\mathrm{NT}$ & 0 & 0 & 0 & 0 \\
S. typhi & 24 & 27 & 24 & 22 & 29 & \\
B. cereus & $\mathrm{NT}$ & $\mathrm{NT}$ & 29 & 27 & - & - \\
C. tropicalis & 22 & 23 & 22 & 20 & 0 & 27 \\
C. albicans & 20 & 24 & 22 & 21 & 0 & 41 \\
C. krusei & 20 & 24 & 23 & 20 & 0 & 40 \\
\hline
\end{tabular}

KEY: $0=$ No zone of inhibition, NT= Not Tested

Compound (1) From Methanol Fraction

Table 4: Minimum inhibitory concentration of compound (1), from methanol fraction of the leaf extract of Sesamum indicum.

\begin{tabular}{llllll}
\hline Concentration & $100 \mu \mathrm{g} / \mathrm{ml}$ & $50 \mu \mathrm{g} / \mathrm{ml}$ & $25 \mu \mathrm{g} / \mathrm{ml}$ & $12.5 \mu \mathrm{g} / \mathrm{ml}$ & $6.25 \mu \mathrm{g} / \mathrm{ml}$ \\
\cline { 1 - 5 } Organisms & & & & & \\
\hline Staphylococcus aureus & - & - & $-*$ & + & + \\
Streptococcus pyogenes & - & - & $-*$ & + & + \\
Salmonella typhi & - & - & $-*$ & + & + \\
Candida albicans & - & - & $-*$ & + & + \\
Candida tropicalis & - & - & $-*$ & + & + \\
Candida krusei & - & - & $-*$ & + & + \\
\hline
\end{tabular}

KEY: - No growth occurred i.e. zones of inhibition/susceptibility of organism to the extract, -* $=$ MIC,$+=$ Growth of organisms i.e. resistance of organism to the extract.

The compound(1) from methanol fraction of Sesamum indicum inhibited the growth of Staphylococcus aureus, Streptococcus pneumonia, Salmonella typhi, Candida albicans, Candida krusei and Candida tropicalis at a concentration of $25 \mu \mathrm{g} / \mathrm{ml}$, with the corresponding MBC at 100 $\mu \mathrm{g} / \mathrm{ml}$ except for Salmonella typhi, and Candida albicans which had their MBC at $50 \mu \mathrm{g} / \mathrm{ml}$.

Table 5: Minimum bactericidal/fungicidal concentration of compound (1), from methanol fraction of the leaf extracts of Sesamum indicum.

\begin{tabular}{llllll}
\hline Concentration & $100 \mu \mathrm{g} / \mathrm{ml}$ & $50 \mu \mathrm{g} / \mathrm{ml}$ & $25 \mu \mathrm{g} / \mathrm{ml}$ & $12.5 \mu \mathrm{g} / \mathrm{ml}$ & $6.25 \mu \mathrm{g} / \mathrm{ml}$ \\
\cline { 1 - 5 } Organisms & & & & & + \\
\cline { 1 - 5 } Staphylococcus aureus & $-*$ & + & + & + & + \\
Streptococcus pyogenes & $-*$ & + & + & + & + \\
Salmonella typhi & - & $-*$ & + & + & + \\
Candida albicans & $-*$ & $-*$ & + & + & + \\
Candida tropicalis & $-*$ & + & + & + & + \\
Candida krusei & & + & + & + & + \\
\hline
\end{tabular}

KEY: - No growth occurred i.e. zones of inhibition/susceptibility of organism to the extract, $-^{*}=\mathrm{MBC} / \mathrm{MFC} ;+=$ Growth of organisms i.e. resistance of organism to the extract. 
Compound (2) From Petroleum Spirit Extract

Table 6: Minimum inhibitory concentration of compound (2), from petroleum spirit fraction of the leaf extract of Sesamum indicum.

\begin{tabular}{llllll}
\hline Concentration & $2 \mathrm{mg} / \mathrm{ml}$ & $1 \mathrm{mg} / \mathrm{ml}$ & $0.5 \mathrm{mg} / \mathrm{ml}$ & $0.25 \mathrm{mg} / \mathrm{ml}$ & $0.125 \mathrm{mg} / \mathrm{ml}$ \\
\cline { 1 - 4 } Organisms & & & & & \\
\hline Staphylococcus aureus & - & - & $-*$ & + & + \\
Streptococcus pyogenes & - & - & $-*$ & + & + \\
Salmonella typhi & - & - & $-*$ & + & + \\
Candida albicans & - & - & $-*$ & + & + \\
Bacillus cereus & - & - & $-*$ & + & + \\
Corynebacterium & - & - & $-*$ & + & + \\
ulcerans & - & - & $-*$ & + & + \\
Candida tropicalis & - & - & $-*$ & + & + \\
Candida krusei & - & - & - & + &
\end{tabular}

KEY: - No growth occurred i.e. zones of inhibition/susceptibility of organism to the extract, $-^{*}=\mathrm{MIC},+=$ Growth of organisms i.e. resistance of organism to the extract.

The compound (2) from petroleum spirit fraction of Sesamum indicum inhibited the growth of Staphylococcus aureus, Streptococcus pyogenes, Salmonella typhi, Candida albicans, Candida krusei, Bacillus cereus, Corynebacterium ulcerans, Escherichia coli and Candida tropicalis at a concentration of $0.5 \mathrm{mg} / \mathrm{l}$, with the corresponding $\mathrm{MBC}$ at $2 \mathrm{mg} / \mathrm{l}$ for Streptococcus pyogenes, Salmonella typhi, Candida albicans, Candida krusei, Corynebacterium ulcerans, Candida albicans, expect for Staphylococcus aureus, Bacillus cereus, and Escherichia coli which had their $\mathrm{MBC}$ at $1 \mathrm{mg} / \mathrm{l}$.

Table 7: Minimum bactericidal/fungicidal concentration of compound (2) from petroleum spirit fraction of the leaf extract of Sesamum indicum.

\begin{tabular}{|c|c|c|c|c|c|}
\hline Concentration & $2 \mathrm{mg} / \mathrm{ml}$ & $1 \mathrm{mg} / \mathrm{ml}$ & $0.5 \mathrm{mg} / \mathrm{ml}$ & $0.25 \mathrm{mg} / \mathrm{ml}$ & $0.125 \mathrm{mg} / \mathrm{ml}$ \\
\hline \multicolumn{6}{|l|}{ Organisms } \\
\hline Staphylococcus aureus & - & $-*$ & + & + & + \\
\hline Streptococcus pyogenes & _* & + & + & + & + \\
\hline Salmonella typhi & -* & + & + & + & + \\
\hline Candida albicans & _* & + & + & + & + \\
\hline $\begin{array}{l}\text { Corynebacterium } \\
\text { ulcerans }\end{array}$ & $-*$ & + & + & + & + \\
\hline Bacillus cereus & - & $-*$ & + & + & + \\
\hline Escherichia coli & - & $-*$ & + & + & + \\
\hline Candida tropicalis & $-*$ & + & + & + & + \\
\hline Candida krusei & -* & + & + & + & + \\
\hline
\end{tabular}

KEY: - No growth occurred i.e. zones of inhibition/susceptibility of organism to the extract, - $^{*}=\mathrm{MBC} / \mathrm{MFC},+=$ Growth of organisms i.e. resistance of organism to the extract.

Compound (3), From Petroleum Spirit Extract

Table 8: Minimum inhibitory concentration of compound (3), from petroleum spirit fraction of the leaf extract of Sesamum indicum.

\begin{tabular}{|c|c|c|c|c|c|}
\hline Concentration & $2 \mathrm{mg} / \mathrm{ml}$ & $1 \mathrm{mg} / \mathrm{ml}$ & $0.5 \mathrm{mg} / \mathrm{ml}$ & $0.25 \mathrm{mg} / \mathrm{ml}$ & $0.125 \mathrm{mg} / \mathrm{ml}$ \\
\hline \multicolumn{6}{|l|}{ Organisms } \\
\hline Staphylococcus aureus & - & - & $-*$ & + & + \\
\hline Streptococcus pyogenes & - & - & $-*$ & + & + \\
\hline Salmonella typhi & - & - & $-*$ & + & + \\
\hline Candida albicans & - & - & $-*$ & + & + \\
\hline Bacillus cereus & - & - & $-*$ & + & + \\
\hline Escherichia coli & - & - & $-*$ & + & + \\
\hline Candida tropicalis & - & - & $-*$ & + & + \\
\hline Candida krusei & - & - & $-*$ & + & + \\
\hline
\end{tabular}


KEY: - No growth occurred i.e. zones of inhibition/susceptibility of organism to the extract, $-^{*}=\mathrm{MIC},+=$ Growth of organisms i.e. resistance of organism to the extract.

The compound (3) a reddish oil from petroleum spirit fraction of Sesamum indicum inhibited the growth of Staphylococcus aureus, Streptococcus pyogenes, Salmonella typhi, Candida albicans, Candida krusei, Bacillus cereus, Corynebacterium ulcerans, Escherichia coli and Candida tropicalis at a concentration of $0.5 \mathrm{mg} / \mathrm{l}$, with the corresponding
MBC at 2mg/l for, Staphylococcus aureus, Salmonella typhi, Candida albicans, Candida krusei, Escherichia coli, Candida albicans, expect for Streptococcus pyogenes, and Bacillus cereus, which had their MBC at $1 \mathrm{mg} / \mathrm{l}$ and Corynebacterium ulcerans without a zone of susceptibility

Table 9: Minimum bactericidal/fungicidal concentration of compound (3), from petroleum spirit fraction of the leaf extract of Sesamum indicum.

\begin{tabular}{|c|c|c|c|c|c|}
\hline Concentration & $2 \mathrm{mg} / \mathrm{ml}$ & $1 \mathrm{mg} / \mathrm{ml}$ & $0.5 \mathrm{mg} / \mathrm{ml}$ & $0.25 \mathrm{mg} / \mathrm{ml}$ & $0.125 \mathrm{mg} / \mathrm{ml}$ \\
\hline \multicolumn{6}{|l|}{ Organisms } \\
\hline Staphylococcus aureus & $-*$ & + & + & + & + \\
\hline Streptococcus pyogenes & - & $-*$ & + & + & + \\
\hline Salmonella typhi & $-*$ & + & + & + & + \\
\hline Candida albicans & $-*$ & + & + & + & + \\
\hline Bacillus cereus & - & $-*$ & + & + & + \\
\hline Escherichia coli & $-*$ & + & + & + & + \\
\hline Candida tropicalis & $-*$ & + & + & + & + \\
\hline Candida krusei & $-*$ & + & + & + & + \\
\hline
\end{tabular}

KEY: - No growth occurred i.e. zones of inhibition/susceptibility of organism to the extract,

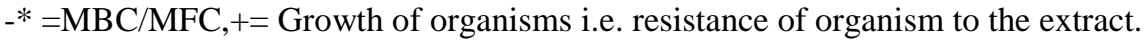

\section{Compound (4) From Chloroform Extract}

Table 10: Minimum inhibitory concentration compound (4), from chloroform fraction of the leaf extract of Sesamum indicum.

\begin{tabular}{lccccc}
\hline Concentration & $2 \mathrm{mg} / \mathrm{ml}$ & $1 \mathrm{mg} / \mathrm{ml}$ & $0.5 \mathrm{mg} / \mathrm{ml}$ & $0.25 \mathrm{mg} / \mathrm{ml}$ & $0.125 \mathrm{mg} / \mathrm{ml}$ \\
\hline Organisms & & & & & \\
\hline Staphylococcus aureus & - & - & - & $-*$ & + \\
Streptococcus pyogenes & - & - & - & $-*$ & + \\
Escherichia coli & - & - & - & $-*$ & + \\
Salmonella typhi & - & - & - & $-*$ & + \\
Candida albicans & - & - & $-*$ & + & + \\
Bacillus cereus & - & - & - & + & + \\
Corynebacterium & - & - & $-*$ & + \\
ulcerans & - & - & $-*$ & + & + \\
Candida tropicalis & - & - & $-*$ & + & + \\
Candida krusei & - & & & + \\
\hline
\end{tabular}

KEY: - No growth occurred i.e. zones of inhibition/susceptibility of organism to the extract, - $^{*}=\mathrm{MIC},+=$ Growth of organisms i.e. resistance of organism to the extract.

The compound (4) a light yellowish oil from chloroform fraction of Sesamum indicum inhibited the growth of Staphylococcus aureus, Streptococcus pyogenes, Salmonella typhi, Bacillus cereus, Corynebacterium ulcerans at a concentration of $0.25 \mathrm{mg} / \mathrm{l}$ and Candida albicans, Candida krusei, Escherichia coli and Candida tropicalis at a concentration of $0.5 \mathrm{mg} / \mathrm{l}$, with the corresponding $\mathrm{MBC}$ at $1 \mathrm{mg} / \mathrm{l}$ for Corynebacterium ulcerans Salmonella typhi, Candida albicans, Candida krusei, Escherichia coli, Candida albicans, expect for Streptococcus pyogenes, Staphylococcus aureus and Bacillus cereus, which had their MBC at $0.5 \mathrm{mg} /$ 1. 
Table 11: Minimum bactericidal/fungicidal concentration compound (4), from chloroform fraction of the leaf extract of Sesamum indicum.

\begin{tabular}{llllll}
\hline Concentration & $2 \mathrm{mg} /$ & $\begin{array}{l}1 \mathrm{mg} / \\
\mathrm{ml}\end{array}$ & $\begin{array}{l}0.5 \mathrm{mg} / \\
\mathrm{ml}\end{array}$ & $\begin{array}{l}0.25 \mathrm{mg} / \\
\mathrm{ml}\end{array}$ & $\begin{array}{l}0.125 \mathrm{mg} \\
/ \mathrm{ml}\end{array}$ \\
\hline Organisms & $\mathrm{ml}$ & $\mathrm{ml}$ & & & + \\
\hline Staphylococcus aureus & - & - & $-*$ & + & + \\
Streptococcus pyogenes & - & $-*$ & + & + & + \\
Salmonella typhi & - & - & $-*$ & + & + \\
Corynebacterium & - & - & $-*$ & + & + \\
Ulcerans & & & & & + \\
Candida albicans & - & $-*$ & + & + & + \\
Bacillus cereus & - & - & $-*$ & + & + \\
Escherichia coli & - & $-*$ & + & + & + \\
Candida tropicalis & - & $-*$ & + & + & + \\
Candida krusei & - & $-*$ & + & + & + \\
\hline
\end{tabular}

KEY: - No growth occurred i.e. zones of inhibition/susceptibility of organism to the extract,

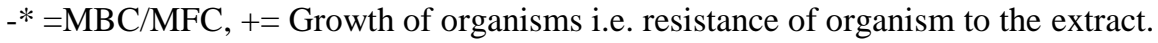

Conclusion: This study illustrates that the leaf extracts of the sesame specie from Benue state region of Nigeria could be a good agent for antimicrobial activities worthy of further investigations. The pure isolates gotten from the various crude solvent extracts were bactericidal against the following organisms tested against; Staphylococcus aureus, Streptococcus pyogenes, Salmonella typhi, Bacillus cereus, Escherichia coli, Corynebacterium ulcerans, Candida albicans, Candida krusei and Candida tropicalis at different MIC and MBC/MFCs. These may account for the activity recorded for it by the traditional users in these region of the country, as these active ingredients are known to be antimicrobial metabolites whose effects are due to the presence of scavenging sites on their moiety. These may also account for the broad spectrum activity observed for it against the test organisms.

Acknowledgement: The Authors of this work wish to appreciate the laboratory personnel's of the department of Chemistry, ABU, Zaria for providing laboratory facility for conducting this research project and the authorities of the Herbarium (Department of the Biological Sciences, ABU, Zaria) and for identifying the plant species used in this study.

\section{REFERENCES}

Birendra, M. and Chhetri, R B.(2012). Indigenous knowledge on medicinal non-timber forest products (NTFP) in parbat district of Nepal. Indo. Global Journal of Pharmaceutical Sciences.; 2(2): 213-225.
Cohen M L., (1992) Epidemiology of drug resistance: implications for a post antimicrobial era. Science. 257:1050-1055. 12.435.

Gills L.S., (1992). Ethnomedical uses of plants in Nigeria, Uniben Press, Edo State Nigeria.; pp 212.

Harborne J.B. (1984) Phytochemical Methods: A Guide to Modern Techniques of Plant Analysis 1 st Ed. Chapman and Hall Ltd. London., pp 49189.

Ijigah, C.E, Amupitan, J.O, Ndukwe, G.I., (2011) Antimicrobial activity of the leaf of the white

specie of Sesamum indicum from Benue State, Nigeria. An M.Sc Thesis in the department of Chemistry, Ahmadu Bello University, Zaria.. Pp 1-74.

Nascimento G. F., Juliana L., Paulo C.F., Giuliana L.S., (2000) Antibacterial activity of plant

extracts and phytochemicals on antibiotic resistant bacteria. Brazilian Journal of Microbiology; 31: $247-256$

Rajeev K.S, Nitesh J., Varadaraj B.G, Hitesh J., (2011) Antioxidant and antimicrobial activities

of Cocos nucifera Linn. (Arecaceae) endocarp extracts. Indo Global Journal of Pharmaceutical Sciences.; 1(4): 354-361.

Salim K., Rajeev K.S, Malik Z.A., (2011) Assessment of phytochemical diversity in Phyllanthus amarus using HPTLC fingerprints. 
Indo Global Journal of Pharmaceutical Sciences.; 1(1): 1-12.

Singla R.K. (2012). Review on the pharmacological properties of Cocos Nucifera Endocarp . WebmedCentral Pharmaceutical sciences;3(5): 98-103

Sofowora, E.A. (1982) Medicinal plants and traditional medicine in Africa ( $1^{\text {st }} \mathrm{ed}$.).

Nigeria: University press of Ife Press., pp.6-160

Sumit N., Rana, A.C, Vinita T., Shaveta, G., Ramica S., (2011) Review on chemical \& pharmacological action of Ocimum kilimandscharicum. Indo Global Journal of Pharmaceutical Sciences.; 1(4) 287-293.

Farraro,M.J, Craig W.A., M.N, .; Dudley G.M.; Eliopoulos, D.W.; Hecht, J.L.; Hindler, B. ;Reller, A.T.; Sheldon, J.M.; Swenson, F.C. ; Tenover, et al.(2000). Performance Standards for Antimicrobial Disk Susceptibility Tests, Approved Standard M2-A7, 7th ed.; National Committee for Clinical Laboratory

Standards: Wayne, PA, USA, pp. 1-26.
Uprety A., (2010) Indigenous use and bio-efficacy of medicinal plants in the Rasuwa district,

Central Nepal. Journal of Ethno biology and Ethno medicine; 6:3.

Vidhu A., Perwez A., Mali, U.K., (2012) Isolation of New Aliphatic Ester Linked with lactone cos11-enyl pentan-1-oic-1, 5-olide from the Roots of Streblus asper Lour. Indo Global Journal of Pharmaceutical Sciences.; 2(2): 114-120.

Virendra Y., Soma J., Arjun P., Rajeev K.S. (2012). Investigation of analgesic \& anti-pyretic

potentials of Callicarpa macrophylla Vahl. leaves extracts. Webmedcentral: International Journal of Medicine and Molecular Medicine; 3(6): 6772 